Liudmyla Denyshchenko, Senior Lecturer, Volodymyr Dahl East Ukrainian National University, pr. Central 59-a, Severodonetsk, 93400, Ukraine,

ORCID: 0000-0002-8160-7343

https://publons.com/researcher/3457613/liudmyla-denyshchenko/

\title{
ANALYSIS OF DISTRIBUTION AND FINANCIAL EFFICIENCY OF TOURIST ENTERPRISES IN UKRAINE
}

The article investigates and analyzes the financial results of tourism enterprises of Ukraine according to the data of the Ministry of Statistics for 2017-2018. The peculiarities of the regions by the indicated indicators are revealed.

Keywords: tourism enterprise, financial indicators, region, profitability, rating.

Relevance of the research topic. Ukrainian tourism business is at a stage of its development, both by types of tourist services and by region. The financial results of a tourism enterprise don't always meet expectations. Official information recently released in Ukraine on many statistics has made it possible to review and analyze regions in terms of performance and trends in 2017-2018. Such a study will create an overall financial portrayal of the tourism business in Ukraine.

Formulation of the problem. Effective functioning of tourism enterprises of Ukraine can be facilitated by the analysis of available statistical information and finding ways to create or transform a certain direction of their activity and increase the profitability.

Analysis of recent research and publications. Among the scholars who have already researched the financial efficiency of the tourism business are Konishcheva N.I., Balashova R.I., Lehan V.M., Sobolev O.O., Sobolev I.I., Zhukov O.O., Zakorin N.D. These authors studied the resources of the travel company as a source of profitability, considered the importance of its business relations with contractors, determined the theoretical approaches to the break-even point in their activities. Now it is possible to examine official statistical information and to try to analyse its data.

Setting objectives. On the basis of the above, it is possible to formulate the task of the study, which is to study and analyze the territorial features in the effectiveness of the activities of tour operators and travel agents in Ukraine. 
Presenting main material. According to the Law of the country «On Tourism» in Ukraine the main types of tourism enterprises are tour operators and travel agents. The law describes their features, namely:

Tour operators are legal entities established under the legislation of Ukraine for which the exclusive activity is the organization and creation of a tourism product, the implementation and provision of tourist services, as well as the intermediary activities for the provision of main and related services and which have been licensed to operate in accordance with the established procedure.

Travel Agents are legal entities established under the legislation of Ukraine, as well as entrepreneurs that mediate the sale of the tourism product of tour operators and tourist services of other entities of tourist activity, as well as intermediary activities for the realisation of characteristic and related services [1].

Since 2019, the Ministry of Statistics of Ukraine provides an opportunity to study and to analyse information on quantitative and qualitative indicators of activity of enterprises of the tourism industry of Ukraine [2]. On the basis of these data, the number of enterprises engaged in tourism activity increased by $5 \%$ compared to 2017 , and the number of entrepreneurs increased by $42 \%$. The largest growth was shown by Kyiv, where the number of tourist enterprises increased by 105 . About half of the regions of Ukraine, by contrast, reduce the number of representatives of the tourist business, including traditionally tourist regions. On average in Ukraine, the income of a tourism enterprises has increased by almost $14 \%$, in particular excursion business has improved the profitability by 55\%. Such dynamics of indicators shows a sustainable development of the tourism industry and confident hopes for further positive dynamics. Unfortunately, the increase in the rate of profitability is accompanied by a corresponding increase in the expenses of the tourism business, among which the highest increase is the cost of labor of workers (37.5\%), the amount of commission expenses (37\%) and other operating expenses (68.7\%). Among the costs of paying for the services of third-party organizations, it is necessary to note the reduction of the cost of rail transport services by $70 \%$ and the visa security for tourists - by $20 \%$. Thus, tourists do not favor trains because of low service, and the start of visa-free travel with a number of countries has reduced the percentage of visa costs. Among the increased cost indicators we have the following: $110 \%$ - expenses for water transport (cruises), $60 \%$ - for bus transportation, $50 \%$ - for food, $40 \%$ - for excursion service. Increasing the level of material costs mentioned has an objective explanation. It is related to the increase in the level of inflation and prices for tourism products, the dependence of the tourism industry on a number of infrastructure services. And this significantly reduces the overall profitability. The structure and cost indicators of tourism enterprises are presented in Figure 1. 


\section{Name and cost of tourism enterprises, thousand $\mathrm{UAH}$}

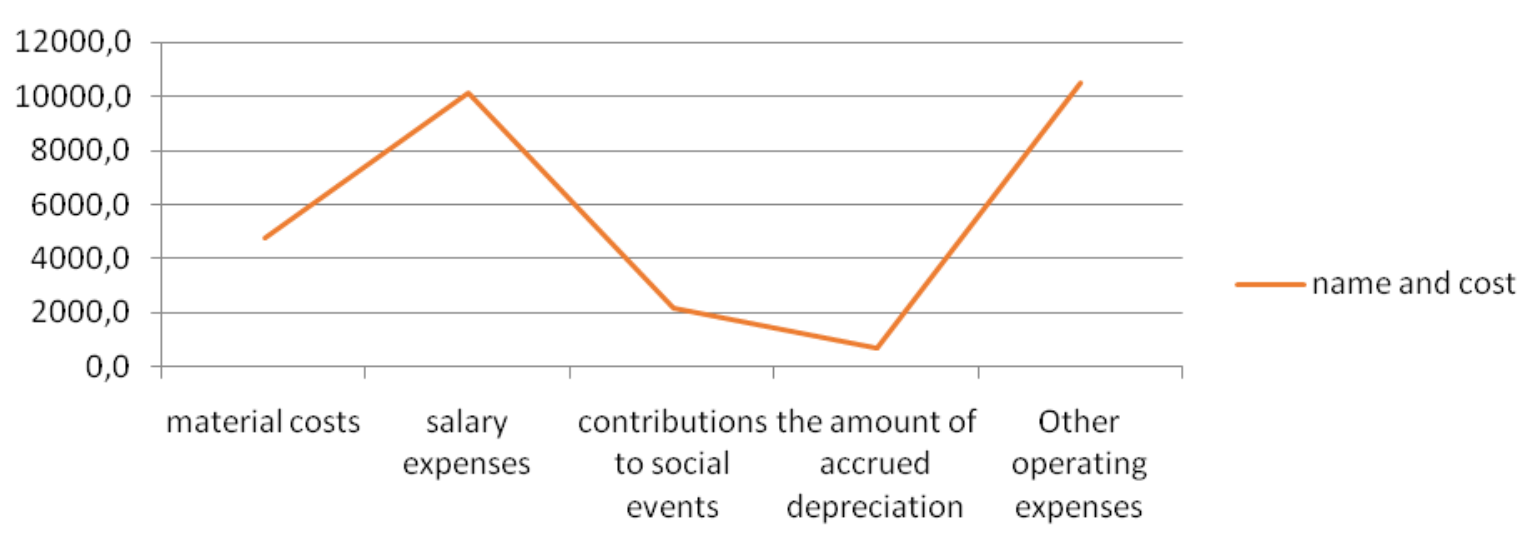

Figure 1. List and cost of tourism enterprises

Unfortunately, financial indicators for only two years do not allow us to form a general idea of sustainable dynamics, but only to see trends in change. Nevertheless, they deserve attention.

Table 1

Financial performance of tourism business enterprises of Ukraine in 2017-2018 [3]

\begin{tabular}{|l|c|c|c|c|c|c|c|c|}
\hline \multirow{2}{*}{\multicolumn{1}{|c|}{ Indicator }} & \multicolumn{2}{|c|}{ Total } & \multicolumn{2}{c|}{$\begin{array}{c}\text { Tour } \\
\text { Operators }\end{array}$} & \multicolumn{2}{c|}{$\begin{array}{c}\text { Travel } \\
\text { agents }\end{array}$} & \multicolumn{2}{c|}{$\begin{array}{c}\text { Subjects of } \\
\text { excursion } \\
\text { activity }\end{array}$} \\
\cline { 2 - 10 } & 2017 & 2018 & 2017 & 2018 & 2017 & 2018 & 2017 & 2018 \\
\hline $\begin{array}{l}\text { Revenue from the provision of tourist } \\
\text { services, mln }\end{array}$ & 18503 & 21070 & 17917 & 20308 & 552 & 715 & 34 & 47 \\
\hline Operating expenses, mln & 14901 & 17926 & 14264 & 17125 & 612 & 772 & 25 & 28 \\
\hline $\begin{array}{l}\text { The financial result of the enterprise, } \\
\text { mln }\end{array}$ & 3602 & 3143 & 3653 & 3182 & -60 & -57 & 8 & 18 \\
\hline Total profitability, \% & 24,17 & 17,54 & 25,61 & 18,58 & $-9,72$ & $-7,36$ & 31,6 & 64,4 \\
\hline
\end{tabular}

According to the data presented in Ukraine, the activity of travel agents in 2017-2018 is unprofitable. Tour operators have some profit, but overall profitability tends to decline. One of the reasons is a big dependence of the tourism business on the political and economic situation in the country, the growth of the US dollar and the euro currency. Outbound tours are particularly sensitive to the rise in foreign exchange rates. On the contrary, the financial results of enterprises engaged in excursion activities are increasing sharply. This indicates an increase in demand for tours of Ukraine. Nevertheless, despite the increase in revenues from domestic excursions, 
unfortunately, they have a low share in the total income of tourist operators, namely, Poltava and Sumy oblasts with leading figures of 20 and $13 \%$ respectively. The lowest available indicator in Ukraine was shown by the Kiev region (5\%).

If we consider the changes by region, we have this result: the leading number of tour operators is in Kyiv (352), Lviv (58), Odessa (17). On the other side, there are no operators at all in Severodonetsk, Kropyvnytskyi and Poltava. About the quantity of travel agents, we have as leaders Kiev (489), Odessa (111) and Dnipro (107 agents). Chernihiv, Zhytomyr, Kherson (11 for each), Severodonetsk (7) have the lowest quantity. Majority of the excursion companies are situated in Kyiv (15), Lviv (12) and Odessa (7), and 11 regions do not have them at all. Thus, the gap between the number of tourism enterprises in the regions of Ukraine is huge.

The table below shows the rating of regions of Ukraine by value of the financial result of activity of tourist operators and agents in 2018.

Table 2

\section{Profitability rating of tour operators and travel agencies in Ukraine}

\section{in 2018 by region}

\begin{tabular}{|l|c|l|c|}
\hline \multicolumn{2}{|c|}{ Financial results of tour operators, ths } & \multicolumn{2}{c|}{ Financial results of travel agencies, ths } \\
\hline Kiev & 2750944,6 & Kherson & 25065,20 \\
\hline Lviv & 290812,9 & Donetsk & 12421,50 \\
\hline Ivano-Frankivsk & 90225,3 & Odesa & 6787,70 \\
\hline Odessa & 36750,6 & Chernivtsi & 5376,90 \\
\hline Volyn & 10402,9 & Kropyvnytskyi & 4362,00 \\
\hline Vinnytsia & 7084,3 & Zaporozhye & 3937,90 \\
\hline Cherkasy & 2902,3 & Dnepropetrovsk & 3919,90 \\
\hline Donetsk & 1520,3 & Kiev region & 2859,20 \\
\hline Dnepropetrovsk & 1340,7 & Zacarpathian & 2750,30 \\
\hline Ternopilska & 1286,0 & Kharkiv & 1924,30 \\
\hline Kiev region & 504,0 & Ternopilska & 1570,40 \\
\hline Zaporozhye & 389,3 & Zhytomyr & 659,00 \\
\hline Sumy & 358,9 & Vinnytsia & 539,70 \\
\hline Chernihiv & 285,1 & Volyn & 493,80 \\
\hline Nikolaev & 140,1 & Poltava & 404,80 \\
\hline Kherson & 124,2 & Sumy & 401,90 \\
\hline Zhytomyr & 93,3 & Ivano-Frankivsk & 382,50 \\
\hline Rivne & 60,6 & Rivne & 353,00 \\
\hline Khmelnytsky & $-9,4$ & Chernihiv & 297,60 \\
\hline Zacarpathian & $-200,1$ & Khmelnytsky & 183,70 \\
\hline Kharkiv & $-474,1$ & Nikolaev & 91,80 \\
\hline Chernivtsi & $-12546,6$ & Lugansk & 26,00 \\
\hline Kropyvnytskyi & & Cherkasy & $-70,30$ \\
\hline Lugansk & & Lviv & $-4058,80$ \\
\hline Poltava & Kiev & $-127516,80$ \\
\hline
\end{tabular}


So, the most effective tourism operators work in Kiev, Lviv and IvanoFrankivsk, and work in Khmelnytskyi, Transcarpathia, Kharkiv and Chernivtsi is unprofitable. Kherson, Donetsk and Odesa are the top ranked travel agents, and Cherkasy, Lviv and Kiev are showing the unprofitableness.

Conclusion. Around the world, there is an increase in tourist flows to different destinations, including domestic ones, each year. The profitability of the tourism business with the appropriate efforts is indisputable, which is confirmed by both the owners of the enterprises and the states receiving a strong tax profit from tourists. In Ukraine, outbound tourism is now dominated by standard tourist attractions of the world, but the possibilities of domestic travel are almost ignored. Activity of excursion firms confirms great opportunities for development of this direction. Our country has the largest territory among the European countries, so it has many tourist resources and opportunities.

According to the conducted research, it is necessary to conclude that there is an uneven placement of representatives of the tourist business on the territory of Ukraine. There may be some reasons for this:

- Uneven development of tourist attractions in the country;

- Insufficient quality of infrastructure of some regions required for tourists;

- Different level of solvency of potential clients of the tourist business;

- The presence of a prolonged military conflict in eastern Ukraine;

- Underdeveloped marketing activities of tourism enterprises, including for the development of domestic tourism, etc.

Thanks to the appropriate actions of the state and the interest of business, Ukrainian tourism has many opportunities and prospects.

\section{REFRENCES}

1. The Law of Ukraine «On Tourism». (n.d.). Retrieved from https://zakon.rada.gov.ua/laws/show/1282-15

2. Rozvytok metodiv otsinky efektyvnosti diialnosti turystychnykh pidpryiemstv. (2008). Visnyk DITB. Seriia: Ekonomika, Orhanizatsiia Ta Upravlinnia Pidpryiemstvamy Turystychnoi Industrii Ta Turystychnoi Haluzi v Tsilomu, 99-108.

3. Ukrstat.org - Publication of documents of the State Statistics Service of Ukraine. (n.d.). Retrieved from https://ukrstat.org/uk/operativ/ operativ2019/tyr/tyr_ dil/arch_tyr_dil.htm 